\section{Turbidimetric method for the determination of serum globulin using the AutoAnalyzer}

\author{
J. H. GLENN From the Department of Routine \\ Chemical Pathology, St. Mary's Hospital, \\ Paddington, London
}

An automatic procedure for the determination of globulin in serum or plasma is described. This method is based on the measurement of the turbidity which develops when serum is mixed with $27.4 \%$ sodium sulphate solution. The method gives good agreement with the salt fractionation technique (Majoor, 1946) and shows a high degree of precision.

The differential estimation of serum proteins constitutes an important fraction of the work in most chemical pathology departments and the automation of these analyses would result in a great saving of time. While there are several adequate methods available for the measurement of total protein (Stevens, 1959; Failing, Buckley, and Zak, 1960), none of the procedures proposed for the albumin estimation has gained wide acceptance.

These latter methods depend on the dye-binding capacity of albumin which has been shown to be influenced by a number of substances, $e . g$., drugs or heparin (Niall and Owen, 1961). In our hands, none of them has given consistent results and has shown poor agreement with the salt-fractionation technique of Majoor. For these reasons, experiments were begun to find, if possible, a more satisfactory method of albumin/globulin determination.

In the course of these, it was discovered that the turbidity produced by mixing serum with $27 \cdot 4 \%$ sodium sulphate varied in a linear manner with globulin content. This observation is the basis of the method to be described.

METHOD

A manifold is constructed as shown in Figure 1. Samples Received for publication 7 February 1964.

Chromosome analysis from human skin-continued.

Ford, C. E. (1962). In Methodology in Human Genetics, edited by W. J. Burdette, p. 233. Holden-Day, San Francisco.

Fox, M., and Zeiss, I. M. (1961). Nature (Lond.), 192, 1213.

Frøland, A. (1961). Acta path microbiol. scand, 53, 319.

Harnden, D. G. (1960). Brit. J. exp. Path., 41, 31.

Hirschhorn, K., and Cooper, H. L. (1961). Amer. J. Med., 31, 442.

Lejeune, M. J., Turpin, R., and Gautier, M. (1960). Rev. franc. Étud. clin biol., 5, 406.

Moorhead, P. S., Nowell, P. C., Mellman, W. J., Battips, D. M., and Hungerford, D. A. (1960). Exp. Cell Res., 20, 613.

Pariente, J. (1961). France méd., 24, (2), 95.

Rothfels, K. H., and Siminovitch, I. (1958). Stain Technol., 33, 73.

Smulow, J. B., Rustigian, R., and Tye, M. (1961). Proc. Soc. exp. Biol. (N.Y.), 106, 757.

Wakonig-Vaartaja, R. (1962). Nature (Lond.), 193, 144.

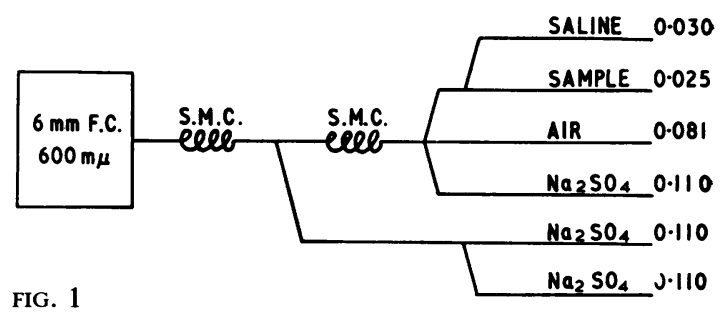

are run at 40/hr. A $6 \mathrm{~mm}$. flow cell is used with a $660 \mathrm{~m} \mu$ filter.

It was found that, in general, blanks are unnecessary because of the high dilution involved. Occasionally in the case of a severely jaundiced or lipaemic specimen blanks may be measured by substituting saline for the sodium sulphate solution.

In this technique the peaks tend to be filled in at the tops, but their outline can easily be discerned. No difficulty has been found in obtaining consistent results, even by relatively inexperienced staff.

The reagents are $0.9 \%$ saline and $27.4 \%$ sodium sulphate, anhydrous. This reagent is kept in a wide-mouth quart size thermos flask at $37^{\circ} \mathrm{C}$. This prevents the salt from crystallizing out when in use.

\section{STANDARDS}

Because of the linearity of this method (see below) and the difficulty in obtaining serum globulin, a departure from the usual method of standardization is adopted. The optical density of each peak is read off and compared with that of a serum whose globulin content has been determined by one of the standard salt-fractionation methods. This may be horse serum or one of the control sera available commercially. In our case Versatol is used. An electrophoretic analysis of this material by the Tiselius technique is available from the manufacturers on request.

To facilitate reading optical densities logarithmic ruled chart paper may be used. Alternatively, a strip of $\log$ ruled chart paper may be stuck along one of the vertical lines on an ordinary general purpose chart reader in such a way that the zero optical density lines coincide with the zero line of the recorder. The optical density of the peaks may then be read off.

\section{CALCULATION}

Optical density of test $\times$ Globulin content of stanOptical density of standard $\times$ dard in $\mathrm{g} . / 100 \mathrm{ml}$.

\section{RESULTS}

The relationship between optical density and globulin content was determined by making serial dilutions from a serum whose globulin content had been assayed by fractionation with $27 \cdot 4 \%$ sodium sulphate and estimation of protein with biuret reagent. Figure 2 shows that this relationship is a linear one.

The reproducibility of the method was checked by dividing samples of serum and submitting them for analysis under different names. The results of 100 


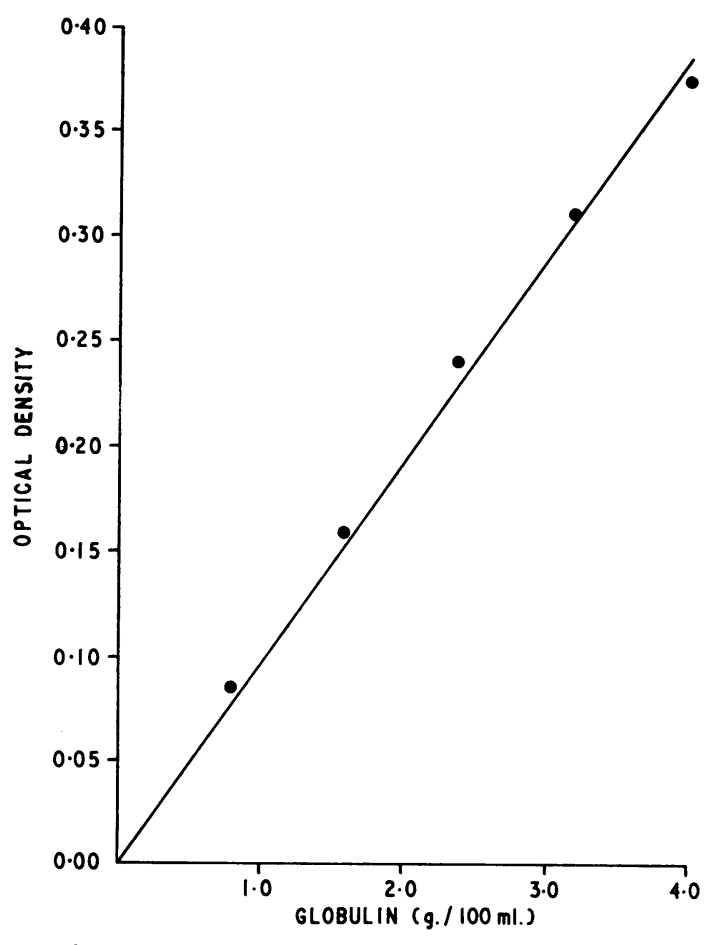

FIG. 2

duplicates showed a mean difference of $0.03 \mathrm{~g} . / 100 \mathrm{ml}$. These results were obtained by junior staff.

Table I shows a series of comparisons between the results for globulin content obtained by the manual technique (Gornall, Bardawill, and David, 1949) and the automatic method. It will be seen that agreement is satisfactory.

Albumin was tested in concentrations up to $10 \mathrm{~g} . / 100$ $\mathrm{ml}$. and was shown not to produce turbidity. It was also shown by diluting serum with saline and with $10 \%$ albumin that albumin had no effect on the turbidity produced with globulin.

The method described has the advantages of speed accuracy, and reproducibility. Also the reagents are simple, cheap, and safe to handle. This method has beeno in routine use for almost a year, during which time non serious difficulties have been encountered.

\section{TABLE I}

COMPARISON OF RESULTS OF GLOBULIN

(g./100 ml.) ESTIMATION BY MANUAL AND AUTOMATIC METHODS

\begin{tabular}{|c|c|}
\hline Manual & Automatic \\
\hline 2.4 & 2.4 \\
\hline $2 \cdot 2$ & $2 \cdot 4$ \\
\hline $2 \cdot 2$ & $2 \cdot 1$ \\
\hline $2 \cdot 5$ & $2 \cdot 4$ \\
\hline $1 \cdot 1$ & $1 \cdot 1$ \\
\hline $2 \cdot 2$ & $2 \cdot 2$ \\
\hline $2 \cdot 8$ & $2 \cdot 8$ \\
\hline $2 \cdot 8$ & $2 \cdot 7$ \\
\hline $3 \cdot 0$ & $3 \cdot 2$ \\
\hline $3 \cdot 7$ & $3 \cdot 5$ \\
\hline $2 \cdot 3$ & $2 \cdot 4$ \\
\hline $2 \cdot 8$ & 3.0 \\
\hline 2.9 & $2 \cdot 8$ \\
\hline $2 \cdot 4$ & 2.5 \\
\hline $3 \cdot 1$ & $3 \cdot 1$ \\
\hline 2.9 & $2 \cdot 7$ \\
\hline $1 \cdot 7$ & $1 \cdot 6$ \\
\hline $2 \cdot 2$ & $2 \cdot 0$ \\
\hline $1 \cdot 8$ & $1 \cdot 6$ \\
\hline & $2 \cdot 8$ \\
\hline$r=0.93$ & \\
\hline$p>0.01$ & \\
\hline
\end{tabular}

I wish to thank Dr. B. J. Houghton for his interest an£ advice during the course of this work.

\section{REFERENCES} Failing, J. F. Jr., Buckley, M. W., and Zak, B. (1960). Amer. J. clin.
Path., 33, 83 .

Gornall, A. G., Bardawill, C. J., and David, M. M. (1949). J. biof Chem., 177, 751 .

Majoor, C. L. H. (1946). Yale J. Biol. Med., 18, 419.

Niall, M. M., and Owen, J. A. (1961). Proc. Ass. clin. Biochem., 130.

Stevens, D. L. (1959). Technicon Instruction Manual. 